\title{
KETIDAKSANTUNAN BERBAHASA WARGANET DALAM KOLOM KOMENTAR IKLAN KINERJA PEMERINTAHAN PRESIDEN JOKO WIDODO BERTAJUK " 2 MUSIM, 65 BENDUNGAN"
}

\author{
A. Haris ${ }^{1}$, Muhammad Salahuddin ${ }^{2}$, Abas Oya ${ }^{3}$ \\ Dosen Sekolah Tinggi Keguruan dan Ilmu Pendidikan Harapan Bima ${ }^{1,2,3}$ \\ abdulharishasan92@gmail.com,muh.ahlan07@gmail.com, abasoya01@gmail.com
}

\begin{abstract}
Youtube is one of the social media that loved by people today. Various kinds of entertainment are broadcast on the Youtube channel, from music, films, documentary videos, news and advertisements. Youtube as means as of entertainment brings out various languages. One variety of language that is interesting to note is the impoliteness of netizen language in the comments column. The purpose of this study is to explain the indecency of warganet language in the advertising comments column of President Joko Widodo's government performance entitled "2 Seasons, 65 Dam" which is analyzed by the theory of Mils, Brown and Levinson and Culpeper and supported by the theory of Hymes, Criper and Widdowson and Pateda to see events. language. This type of research is qualitative using a sociopragmatic approach. The method used is descriptive method. The data source for this research comes from Youtobe social media. The data used in this study are related to diction, phrases and sentences. Data collection techniques in this study using document techniques. The data analysis technique used descriptive analysis techniques. The results of this study are that in Mils' theory, it is found that language impolitence is motivated and language impoliteness is not motivated. Brown and Levinson's theory found language impropriety related to actions that threaten the opponent's negative face and actions that threaten the opponent's positive face. Meanwhile, Culpeper's theory found that language impoliteness is related to direct impoliteness, pseudo politeness, and withholding politeness. Judging from the Hymes language event theory in the acronym SPEAKING, the elements that are violated by warganet are A, K and N. Impolitence according to Criper and Widdowson's and Pateda's theory is influenced by the advertising message and the place where the speech occurs.
\end{abstract}

Keywords: Impoliteness language, netizen, advertisement

Abstrak. Youtobe salah satu media sosial yang banyak digandrungi oleh masyarakat dewasa ini. Pelbagai macam hiburan disiarkan dalam kanal Youtobe, mulai musik, film, video dokumenter, berita maupun iklan. Youtobe sebagai sarana hiburan memunculkan pelbagai ragam bahasa. Salah satu ragam bahasa yang menarik untuk diperhatikan ialah ketidaksantunan berbahasa warganet dalam kolom komentar. Tujuan penelitian ini untuk menjelaskan ketidaksantunan berbahasa warganet dalam kolom komentar iklan kinerja pemerintahan Presiden Joko Widodo bertajuk" 2 Musim, 65 Bendungan" yang dianalisis dengan teori Mils, Brown dan Levinson maupun Culpeper dan didukung dengan teori Hymes, Criper dan Widdowson maupun Pateda untuk melihat peristiwa bahasa. Jenis penelitian ini ialah kualitatif dengan menggunakan pendekatan sosiopragmatik. Metode yang digunakan metode deskriptif. Sumber data penelitian ini berasal dari media sosial Youtobe. Adapun data yang digunakan dalam penelitian ini berkaitan dengan diksi, frasa dan kalimat. Teknik pengumpulan data dalam penelitian ini menggunakan teknik dokumen. Teknik analisis data menggunakan teknik analisis deskriptif. Adapun hasil penelitian ini ialah bahwa dalam teori Mils ditemukan ketidaksantunan berbahasa termotivasi dan ketidaksantunan berbahasa tidak termotivasi. Teori Brown dan Levinson ditemukan ketidaksantunan berbahasa yang berkenaan dengan tindakan yang mengancam muka negatif lawan tutur dan tindakan yang mengancam muka positif lawan tutur. Sementara teori Culpeper ditemukan ketidaksantunan berbahasa berkaitan dengan ketidaksantunan secara langsung, kesantunan semu, dan menahan kesantunan. Ditinjau dari teori peristiwa bahasa Hymes dalam akronim SPEAKING unsur yang dilanggar warganet yaitu A, K dan N. Ketidaksantunan menurut teori Criper dan Widdowson maupun Pateda, dipengaruhi oleh pesan iklan dan tempat terjadinya tuturan.

Kata kunci: Ketidaksantunan berbahasa, warganet, iklan

\section{PENDAHULUAN}

Manusia dalam menjalani aktivitas di lingkungan sosial tidak lepas dari berbahasa. Secara pragmatis, berbahasa merupakan salah satu tindakan yang lazim disebut dengan tindak tutur (Ekawati, 2017). Gunawan (2013) mengemukakan bahwa bahasa merupakan alat yang digunakan manusia untuk berkomunikasi. Bahasa sebagai alat komunikasi digunakan untuk menyampaikan gagasan pembicaraan dengan variasi sesuai konteks komunikasi baik dalam lingkungan keluarga, sekolah dan lingkungan masyarakat serta di media sosial. Wahyudin (2013) mengatakan bahwa bahasa digunakan oleh individu untuk meng-ungkapkan berbagai macam perasaannya, mulai dari rasa senang, sedih, atau marah. Bahasa dapat diartikan pula 
sebagai ujaran pikiran yang disampaikan dengan teratur melalui media bunyi.

Perkembangan media sosial sebagai alat komunikasi dewasa ini begitu pesat dan canggih, sehingga memberikan kemudahan dalam aktivitas interaksi dengan orang lain. Menurut Kemenkominfo (2018) pengguna internet di Indonesia mencapai angka 63 juta orang. Presentase tersebut menunjukkan bahwa 95\% orang Indonesia menggunakan internet untuk mengakses media sosial. Sebagai media komunikasi, kehadiran media sosial di dalam aktivitas berbahasa menimbulkan fenomenafenomena kebahasa-an. Salah satu media sosial yang sering ditemukan terjadinya fenomena kebahasaan adalah Youtobe. Salah satu fenomena kebahasaan dalam media sosial Youtobe yang dapat dicermati berkenaan dengan perilaku ketidaksantunan berbahasa yang dilakukan oleh warganet.

Salah satu fenomena ketidaksantunan berbahasa di Youtobe yang dilakukan warganet akhir-akhir ini dikarenakan adanya penayangan iklan yang menyimpang dari tempatnya. Iklan tersebut dipasang oleh pemerintahan Presiden Jowidodo di bioskop yang memuat kinerja Presiden Joko Widodo dalam melakukan pembangunan waduk dan bendungan dengan tajuk "2 Musim, 65 Bendungan". Walaupun iklan yang ditayangkan mengenai hal yang positif banyak warganet yang beranggapan bahwa iklan tersebut dinilai sebagai bentuk kampanye, pencitraan dan penempatan iklan dinilai tidak pantas karena mengganggu kenyamaan publik yang pada akhirnya menimbulkan aktivitas berbicara yang melanggar maksim kesantunan berbahasa.

Adanya penayangan iklan di bioskop yang dilakukan oleh pemerintah Presiden Joko Widodo tersebut, dikutip dari Detiknews (2018), Ferdinandus Setu perwakilan Kominfo, di bagian Kepala Biro Humas Kementerian Kominfo beranggapan bahwa "Iklan tersebut bukan kampanye Pak Jokowi. Iklan tersebut memang disiapkan oleh Kementerian Kominfo yang salah satu tugasnya sebagai Goverment Public Relation atau menjadi Humas Pemerintah". Lebih lanjut, Ferdinandus Setu mengatakan bahwa "Iklan yang ditayangkan di bioskop tersebut adalah salah satu cara Kemkominfo menyampaikan apa yang dikerjakan pemerintah kepada para penonton bioskop".

Meskipun Ferdinandus Setu mengatakan bahwa iklan yang ditayangkan di bioskop adalah salah satu cara Kemkominfo menyampaikan yang dikerjakan pemerintah dan terbebas dari unsur kampanye. Para ahli lainnya membantah pernyataan tersebut seperti Ferdinan Hutahaean, Suryo Prabowo sebagai Mantan Kepala Staf Umum TNI dan Fadli Zon. Pembatahan iklan tersebut dilansir dari Tribunnews (2018) berdasarkan hasil cuitan dari akun Twiiter masng-masing. Ferdinan Hutahaean mengatakan bahwa "Steve Jobs, tidak pernah mengiklankan dirinya, Jack Ma juga tidak, itulah orang-orang yang berhasil! Mengiklankan diri kok berlebihan sampai masuk ke ranah private bioskop. Sadar ya kalau sudah tidak diinginkan rakyat lagi". Sedangkan Suryo Prabowo sebagai Mantan Kepala Staf Umum TNI mengatakan bahwa "Relawan Jokowi melakukan kecurangan karena menyuri star dengan mengiklankan diri di bioskop dan mempertanyakan keelektabilitas Presdiden Joko Widodo". Sementara Fadli Zon menyarankan iklan yang ditayangkan di bioskop tersebut harus dicopot.

Walaupun mendapat tanggapan kritik, dilansir dari laman Detiknews dan Tribunnews, Ferdinandus Setu mengatakan bahwa pihak Kemkominfo tidak akan mencopot iklan yang ditayangkan walau ada permintaan (Fadli Zon) karena Kemkominfo menjalankan tugas yang dibebankan Undang-Undang No 39 Tahun 2008 mengenai Kementrian Negara, Peraturan Presiden No 54 Tahun 2015 dan Inpres No 9 Tahun 2015. Sebagai Humas Pemerintah, Kementrian Kominfo RI selalu berupaya menyampaikan program, kebijakan, kegiatan dan kecapaian, baik yang sudah, sedang, dan akan dilakukan oleh pemerintah kepada publik melalui berbagai saluran yang tersedia, termasuk melalui iklan layanan masyarakat. Lebih lanjut, Ferdinandus Setu mengatakan bahwa penayangan iklan layanan masyarakat di bioskop dipilih sebagai salah satu kanal karena dinilai tepat sasaran mengingat jumah penontonnya terukur serta anggaran yang digunakan untuk iklan layanan masyarakat tersebut dibebankan pada DIPA Kementerian Kominfo Tahun 2018 
yang proses peren-canaannya telah disiapkan sejak pertengahan 2017.

Walaupun telah mendapatkan pernyata-an demikian, para warganet tidak mem-percayai sepenuhnya yang telah disampaikan. Kekecewaan warganet terhadap iklan yang ditayangkan tersebut dikarenakan tidak adanya pernyataan dari Presiden Joko Widodo yang mengatakan bahwa pem-bangunan yang dilakukan dilanjut dari program pemerintah sebelumnya. Hal itu dapat dilihat dari kolom komentar iklan tersebut. Salah satu akun bernama Black7 7lotust mengatakan bahwa "sadar gak itu sudah dibangun zaman SBY wkwkwk-wkwkw kasihan itukan ada di daerah saya, ini nyata .....Pendukung lebay". Sejalan dengan itu, pemilik akun Rizki Saputra mengatakan bahwa "16 bendungan zaman SBY dan sisanya Pak Jokowi.. per-tanyaannya di daerah mana saja itu? Ada link gak? Atau hanya ucapan saja?. Selain faktor penempatan iklan, penyebab kekecewaan warganet terhadap iklan yang ditayangkan dikarenakan pemerintah melakukan pem-bangunan waduk dan bendungan namun bertolakbelakang dengan perilakunya yang melakukan impor beras sampai jutaan ton. Hal itu dapat dilihat dari komentar pemilik akun bernama Herman Saputra yang mengatakan "Iklannya pertanian tapi beras impor. Miris yang bikin ketawa ya ini".

Faktor kekecewaan dari warganet atas iklan tersebut mengakibatkan aktivitas ketidaksantunan berbahasa yang sering kali terlihat dari kolom komentar iklan tersebut. Ketidaksantunan tersebut merupakan suatu rangkaian peristiwa bahasa. Hal itu dikarena-kan adanya interaksi lingusitik, adanya kejadian komunikasi yang terdiri dari satu atau lebih ujaran (Pateda, 1987). Menurut Criper dan Widdowson (dalam Allen dan Corder, 1975) dalam peristiwa bahasa ada hal yang perlu diperhatikan yaitu berkaitan dengan pembicara (addresser), pendengar (addressee), maupun pesan/ berita (message). Pateda (1987) mengatakan bahwa dalam terjadinya peristiwa bahasa ada tiga faktor yang menentukan. Pertama, setting, berhubungan dengan dimensi waktu dan tempat. Kedua, topik, berkaitan dengan yang menjadi unsur pembicaraan. Ketiga, kode, berhubungan dengan makna ujaran.
Hymes (dalam Pateda,

1987) mengemukakan bahwa terdapat beberapa komponen yang harus diperhatikan dalam peristiwa bahasa. Komponen-komponen itu diklasifikasi menjadi delapan komponen yang diakronimkan dalam kata SPEAKING. Komponen $\mathrm{S}$ merupakan berkaitan dengan setting (latar yang berhubungan dengan dimensi waktu dan tempat) dan scene (yakni tafsiran terhadap situasi). Komponen $\mathrm{P}$ yaitu participants yang berhubungan dengan spreker (pembicara), hoorder (pendengar), teohoorder (pendengar yang ikut serta) maupun bron (sumber). Komponen E ialah ends yaitu berkaitan dengan fungsi bahasa dan tujuan pendengar dan pendengar yang ikut serta. Komponen A yaitu act sequence berhubungan dengan bentuk atau ujaran (vorm) dan pesan atau berita (inhoud). Komponen $\mathrm{K}$ artinya key berhubungan dengan jenis aksen yang menyertai misalnya pembicaraan jenis ironi atau sarkasme (toonsoort). Komponen I yaitu instrumenta-lities yang berhubungan dengan variasi bahasa (taalvarietteit) dan alat yang dipergunakan (kanaal). Komponen $\mathrm{N}$ ialah norms yang berhubungan dengan norma-norma interaksi (berhubungan dengan cara mengintrupsi) dan norma penafsiran. Kom-ponen $G$ merupakan genres berhubungan dengan bentuk penyampaian. Berdasarkan pemikiran itu maka untuk melakukan analisis ketidaksantunan berbahasa dalam kolom komentar iklan tersebut harus berlandaskan pada komponen peristiwa bahasa.

Aktivitas berbahasa yang dilakukan warganet di dalam kolom komentar iklan bertajuk "2 Musim, 65 Bendungan" yang ditayangkan di bioskop dinilai tidak santun dikarenakan melanggar maksim-maksim kesantunan berbahasa. Kesantunan merupakan sikap yang berkaitan dengan kesopanan, rasa hormat, sikap yang baik dan perilaku yang pantas (Gunawan, 2013). Menurut Wijayanto, (2014) secara umum konsep ketidaksantunan dibedakan menurut tujuan penggunaannya dan konteks yang melatarbelakanginya. Sementara Leech (dalam Rahardi, dkk, 2016) mengatakan bahwa seseorang dianggap tidak santun dalam berbahasa apabila melanggar maksim kesantunan berbahasa. Maksim-maksim 
kesantunan berbahasa tersebut dapat dikelompokkan dalam enam maksim, meliputi tact maxim (maksim kebijaksanaan), generosity maxim (maksim kedermawanan ), appobation maxim (maksim penerimaan), modesty maxim (maksim kerendahan hati), agreement maxim (maksim kesetujuan), dan sympathy maxim (maksim kesimpatian).

Menurut Culpeper (1996) indikasi ketidaksantunan apabila di dalam perilaku komunikasi seseorang berniat menyerang muka mitra tutur atau menyebabkan mitra tutur merasa diserang. Artinya perilaku komunikasi dianggap tidak santun apabila penutur menyerang mitra tutur atau tergantung respon mitra tutur dari ucapan penutur. Menurut Mills (2003) prilaku ketidaksantunan hanya dapat dipahami dan dianalisis secara pragmatik ketika dikaitkan dengan pemahaman kelompok ujuran dan hanya dalam terma dari berbagai strategi wacana yang luas antarpenutur. Ketidak-santunan harus dilihat dari berbagai penilaian perilaku penutur dan bukan kualitas intrinsik penutur. Pola ketidaksantunan itu merupakan dilihat dari niat penutur.

Ditinjau dari tujuan dan niat, ketidaksantunan dibagi menjadi dua kategori yaitu ketidaksantunan termotivasi dan ketidaksantunan tidak termotivasi. Ketidaksantunan termotivasi ialah penutur diasumsikan telah berniat melakukan tindak ketidaksantunan dengan tujuan tidak santun. Ketidaksantunan tidak termotivasi adalah tindak ketidaksantunan yang tidak bertujuan tidak santun. Tidak diniatkan artinya tidak memahami bahwa hal yang dilakukan tidak santun. Ketidakpahaman tersebut dapat disebabkan berbagai faktor, misalnya budaya yang berbeda (berhubungan dengan etnik), pemahaman konteks yang berbeda, atau faktor kedekatan (Mills, 2003).

Menurut Brown dan Levinson (1987) ketidaksantunan didasari oleh face threatning act atau tindakan tidak menyenangkan yang mengancam muka. Tindakan mengancam muka terbagi menjadi dua kategori, tindakan yang mengancam muka negatif dan tindakan yang mengancam muka positif. Tindakan yang mengancam muka negatif meliputi a) tindakan yang mengakibatkan mitra tutur menyetujui dan menolak melakukan sesuatu seperti ungkap-an: orders and requests, suggestions, advice, reminding threats, warnings, dears (memerintah, cemoohan, memberi saran, memberi nasihat, mengingatkan, mengancam, memperingatkan, dan menentang); (b) tindakan yang mengungkapkan upaya penutur melakukan sesuatu terhadap lawan tutur dan memaksa lawan tutur untuk menerima atau menolak tindakan tersebut, seperti ungkapan mengenai offers, promises (menawarkan dan berjanji); (c) tindakan yang mengungkapkan keinginan penutur untuk melakukan sesuatu terhadap lawan tutur atau dimiliki oleh lawan tutur, seperti ungkapan mengenai compliments, expres-sions of strong emotions towerd, hatred, anger (pujian dan memberi ucapan selamat, mengagumi, membenci maupun marah).

Tindakan yang mengancam muka positif berkaitan dengan; a) tindakan yang memperlihatkan bahwa penutur memberi penilaian negatif terhadap mitra tutur, misal ungkapan disapproval, criticism, contempt or ridicule, complaints and reprimands, accusations, insults (mengungkapkan sikap tidak setuju, mengkritik, tindakan merendahkan, keluhan, kemarahan, dakwaan dan penghinaan); b) tindakan yang memperlihatkan sikap tidak peduli penutur terhadap muka positif mitra tutur, seperti ungkapan: contradictions or disagreements, challenges, emitions, irreverence, mention of taboo topiks, including those that are inappropriate in the context (ketidaksetujuan, tantangan, emosi, ungkapan yang tidak sopan, membicarakan hal tabu ataupun yang tidak selayaknya dalam situasi, yaitu penutur menunjukkan tidak menghargai nilai-nilai lawan tutur dan tidak ingin meninggalkan perihal yang ditakuti lawan tutur; c) ungkapan mengenai bad news about $H$, or good news (boasting) abaout $S$ ( $S$ indicates that he willing to cause distress to $H$, and/or doesn't care about H's feeling) (ungkapan kabar buruk mengenai lawan tutur atau menyombongkan berita baik, yaitu yang menunjukkan bahwa penutur tidak segan menunjukkan sikap yang kurang men-yenangkan dan tidak memedulikan perasaan mitra tutur); d) ungkapan bersifat membahayakan dan topik yang bersifat memecah belah pendapat, seperti masalah topik, ras, agama dan pembebasan wanita. Penutur dalam hal itu 
menciptakan suasana yang dapat mengancam muka mitra tutur yaitu penutur membuat atmosfir yang berbahaya terhadap mitra tutur; e) ungkapan yang tidak koopratif dari penutur ke mitra tutur, seperti penutur menyela pembicaraan lawan tutur dan tidak menunjukkan kepedulian. Penutur menunjukkan bahwa dia tidak mempedulikan keinginan muka negatif maupun muka positif mitra tuturnya; f) unkapan-ungkapan mengenai sebutan dan menunjuk-kan status mitra tutur pada perjumpaan pertama. Situasi itu, penutur membuat identifikasi yang keliru mengenai mitra tutur yang melukai perasaan atau mempermalu-kannya baik secara sengaja maupun tidak sengaja.

Menurut Culpeper (1996) bentuk ketidaksantunan meliputi bald on record impoliteness (ketidaksantunan secara langsung), positive impoliteness (ketida-ksantunan positif), negative impoliteness (ketidaksantunan negatif), sarcasm or mock politeness (sarkasme atau kesantunan semu), dan withhold politeness (menahan kesan-tunan). Bentuk ketidaksantunan Culpeper didasari dari teori yang dikemukakan Brown dan Levinson. Ada lima ketidaksantunan yang dikemukakan Brown dan Levinson (1987), yaitu bald on record impoliteness (ketidaksantunan secara langsung), ketidaksantunan tersebut didasari dengan tindakan yang mengancam muka mitra tutur secara langsung, jelas, tidak ambigu dan ringkas dalam keadaan wajah tidak relevan atau diminimalkan tidak perlu dihubungkan dengan muka. Kedua, positive impoliteness (ketidaksantunan positif), strategi yang ditujukan untuk merusak wajah positif mitra bicara. Ketidaksantunan positif berupa tindakan mengabaikan, menganggap mitra tutur tidak ada, memisahkan diri, tidak simpatik, menggunakan penanda identitas/ sebutan tidak tepat, menggunakan bahasa rahasia yang tidak dimengerti mitra tutur, menggunakan bahasa tabu, kasar atau profan, menggunakan julukan yang menghina dalam menyapa. Ketiga, negative impoliteness (ketidaksantunan negatif), bertujuan untuk merusak wajah negatif mitra tutur. Strategi itu meliputi menakut-nakuti (menanamkan keyakinan bahwa tindakannya akan merugikan), merendahkan, mencemooh, menghina, tidak memperlakukan mitra tutur dengan serius, meremehkan mitra tutur, menyerang orang lain (menyerobot kesempatan), menggunakan kata ganti orang yang negatif maupun menempatkan orang lain yang memiliki tanggungan. Keempat, sarcasm or mock politeness (sarkasme atau kesantunan semu), kesantunan yang tidak tulus, berpura-pura atau tampak santun dipermukaan.. Kelima, withhold politeness (menahan kesantunan ), perilaku yang tidak mengucapkan rasa terima kasih pada lawan tutur ketika memberikan hadiah, ucapan selamat maupun ketika dibantu.

Penelitian mengenai ketidaksantunan berbahasa telah dilakukan oleh Muslim (2017) dengan judul Penyimpangan Teori Brown dan Levinson dalam Tindak Tutur Peserta Talk Show Indonesia Lawyers Club (ILC) di TV One dan Relevansinya terhadap Pembelajaran Bahasa Indonesia di SMA. Penelitian tersebut dianalisis dengan teori Brown dan Levinson. Hasil penelitiannya menunjukkan bahwa ketidaksantunan yang terjadi ialah pengancaman muka positif dan pengancaman muka negatif. Tuturan peserta mengancam muka positif berupa keluhan, dakwaan, ketidaksetujuan, kritikan, ungka-pan yang tidak koopratif, mempermalukan lawan tutur, dan kata-kata tabu. Ungkapan pengancaman muka negatif merupakan penolakan, saran, nasihat, permintaan, larangan, janji dan pujian. Ketidaksantunan yang terjadi untuk memperoleh keadilan, pembelaan diri sendiri, solidaritas kelompok, kekuasaan, pengakuan diri dan kelompok, penegakan hukum, perjuangan melawan korupsi dan pembelaan atas nama rakyat. Perilaku ketidaksantunan tersebut menguna-kan tindak tutur direktif, deklaratif, ekspresif, dan refresentatif. Penelitian tersebut memiliki relevansi dengan pembelajaran bahasa Indonesia di SMA kelas XI semester II, KD 9.2 dengan materi pokok cara memberikan komentar pada acara diskusi.

Penelitian ketidaksantunan berbahasa dilakukan juga Fatimah dan Zainal (2014) dengan judul Strategi Ketidaksantunan Culpeper dalam Berbahasa Lisan di Sekolah. Penelitian yang dilakukan oleh Fatimah dan Zainal dianalisis dengan menggunakan teori ketidaksantunan Culpeper. Adapun hasil penelitiannya menunjukkan bahwa strategi ketidaksantunan Culpeper dalam berbahasa lisan 
di sekolah antara lain penggunaan strategi (1) ketidaksantunan secara langsung (bald on record impoliteness), (2) ketidak-santunan positif (positive impoliteness), (3) ketidaksantunan negatif (negative impo-liteness), (4) sarkasme atau kesantunan semu (sarcasm or mock politeness), maupun (5) menahan kesantunan (withhold politeness).

Walaupun penelitian ini menganalisis mengenai ketidaksantunan berbahasa, namun terdapat beberapa perbedaan yang dilakukan peneliti dengan penelitian yang dilakukan Muslim serta Fatimah dan Zainal. Perbedaan tersebut terletak dari objek yang diteliti. Objek kajian yang dilakukan Muslim yaitu acara talkshow ILC sedangkan Fatimah dan Zainal objek kajiannya mengenai bahasa lisan di sekolah. Kedua penelitian tersebut mengkaji ketidaksantunan berbahasa dengan menggunakan teori Culpeper, Brown dan Levinson. Objek penelitian ini ialah iklan yang dikaji dengan teori Mills, Brown dan Levinson maupun Culpeper dan didukung teori Hymes, Criper dan Widdowson maupun Pateda untuk melihat peristiwa bahasa.

Berdasarkan pemaparan pemikiran di atas adapun tujuan dari penelitian ini ialah menjelaskan secara komprehensif ketidaksantunan berbahasa warganet dalam kolom komentar iklan kinerja pemerintahan Presiden Joko Widodo "2 Musim, 65 Bendungan" yang dikaji dengan teori Mils, Brown dan Levinson, maupun Culpeper dan didukung dengan teori Hymes, Criper dan Widdowson maupun Pateda untuk melihat peristiwa bahasa dalam perilaku ketidak-santunan berbahasa.

\section{METODE PENELITIAN}

Penelitian ini ialah kualitatif. Jenis penelitian yang menggunakan teori-teori yang digunakan untuk mengkaji permasalah-an penelitian. Artinya fenomena-fenomena ketidaksantunan berbahasa warganet dalam kolom komentar iklan "2 Musim, 65 Bendungan" dikaji dengan teoriteori yang digunakan dan dimanfaatkan sebagai acuan penelitian agar fokus yang dianalisis tercapai. Pendekatan penelitian ini ialah pendekatan sosiopragmatik. Penggunaan pendekatan pragmatik untuk meninjau peristiwa bahasa dari segi makna pembicara, konteks, makna dan bentuk menurut jarak sosial yang membatasi partisipan yang terlibat dalam aktivitas tuturan. Metode penelitian ini ialah metode deskriptif. Metode deskriptif diguna-kan untuk memahami dan menjelaskan secara komprehensif mengenai ketidak-santunan berbahasa warganet.

Sumber data penelitian ini berasal dari Youtobe berkaitan dengan iklan kinerja pemerintah Presiden Joko Widodo yang bertajuk "2 Musim, 65 Bendungan". Dipilih-nya iklan tersebut sebagai sumber data dalam penelitian ini dikarenakan banyak sekali terlihat perilaku ketidaksantunan berbahasa yang digunakan warganet yang diarahkan pada pemerintahan Presiden Joko Widodo. Adapun data yang digunakan dalam penelitian ini berupa diksi, frasa dan kalimat dari kolom komentar warganet dalam iklan.

Teknik pengumpulan data dalam penelitian ini menggunakan teknik dokumen dikarenakan data yang dikumpulan berupa nontulisan yaitu berupa iklan. Teknik pengumpulan data dalam penelitian ini dilakukan dengan cara memilih sumber data, mentranskripsi komentar warganet dalam iklan "2 Musim, 65 Bendungan", membaca secara itensif hasil transkripsi komentar-komentar warganet, mengidentifikasi data, menyeleksi dan mengelompokkan data berdasarkan indikator permasalahan yang dikaji. Teknik analisis data yang digunakan ialah teknik analisis deskriptif. Teknik analisis deskriptif dalam peneltian ini dimulai dengan menginterpretasikan data yaitu memberikan penjelasan mengenai data. Tahap menganalisis data ialah menjabarkan data berdasarkan teoriteori yang dipakai. Tahap penarikan simpulan akhir berkenaan dengan menyajikan data yang telah diinterpretasi dan dianalisis.

\section{HASIL DAN PEMBAHASAN}

Aktivitas berbahasa tidak dapat dilepaskan dalam kehidupan manusia. Hal itu dikarenakan setiap hari manusia dalam berkomunikasi selalu menggunakan bahasa. Aktivitas berbahasa dalam Youtobe saat ini sering kali mengggunakan bahasa yang tidak santun. Penggunaan bahasa yang tidak santun tersebut merupakan bagian yang harus dikaji lebih dalam untuk meninjau faktor yang mempengaruhinya. Bagian 
pembahasan ini memfokuskan pada permasalahan yang berkaitan dengan ketidaksantunan berbahasa warganet dalam kolom komentar iklan kinerja pemerintahan presiden joko widodo bertajuk "2 Musim, 65 Bendungan" yang ditayangkan di bioskop, dikaji dengan teori Mils, Brown dan Levinson, maupun Culpeper dan didukung dengan teori Hymes, Criper dan Widdowson maupun Pateda untuk melihat peristiwa bahasa. Permasalahan yang berkaitan dengan perilaku ketidaksantunan berbahasa tersebut dapat diuraikan berikut ini.

\section{Ketidaksantunan Berbahasa Warganet Menurut Pandangan Mils}

Mills mengategorikan perilaku ketidaksantunan berbahasa dalam dua kategori yaitu ketidaksantunan berbahasa termotivasi dan ketidaksantunan berbahasa tidak termotivasi. Kedua kategori ketidaksantunan bahasa tersebut ditemukan dalam kolom komentar iklan kinerja pemerintahan Presiden Joko Widodo bertajuk "2 Musim, 65 Bendungan". Adapun perilaku ketidaksantunan berbahasa tersebut dapat diuraikan dalam data-data berikut ini.

\section{Ketidaksantunan Termotivasi}

Ketidaksantunan termotivasi adalah penutur diasumsikan telah berniat melakukan tindak ketidaksantunan dengan tujuan tidak santun. Ketidaksantunan termotivasi yang dilakukan oleh warganet dalam kolom komentar iklan kinerja pemerintah Presiden Joko Widodo bertajuk "2 Musim, 65 Bendungan" dapat dilihat pada data-data berikut ini.

(1) Utang kita sudah brpa bro? Dana haji udh kpakai brpa bro? Persekusi di negeri demokrasi gmna bro? Import garam besar"an ya bro? Rupiah makin ngga berhrga ya bro? Salah satu aja beritanya bro,,, pemerintah GAGAL.

Pada data (1) di atas menunjukkan perilaku ketidaksantunan berbahasa termoti-vasi yang dilakukan oleh warganet. Perilaku ketidaksantunan berbahasa termotivasi tersebut terjadi dikarenakan penutur mem-punyai niatan langsung memprotes iklan yang ditayangkan oleh pemerintah Presiden Joko Widodo. Niatan penutur tersebut ditandai dengan pertanyaan mengenai banyaknya utang negara, dana haji yang dipakai oleh pemerintah, hukum perkusi yang timpang, pengimporan yang meningkat, kurs rupiah yang rendah. Tinjaun dari Teori Hymes dalam dalam akronim SPEAKING penutur melanggar peristiwa bahasa dalam unsur $\mathrm{A}, \mathrm{K}$, dan $\mathrm{N}$ yang berkaitan dengan bentuk ujaran, sarkasme dan norma interaksi. Terlebih terdapat kata 'Bro dan pemerintah GAGAL' yang digunakan penutur dalam menyapa kepala negara dan mengganggap pemerintahannya gagal. Kata Bro yang disampaikan menandakan antara penutur dan mitra tutur tidak ada batasan sosial. Ditinjau dari teori Criper dan Widdowson bahwa ketidaksantunan itu terjadi karena pesan dari iklan yang tidak sesuai dengan realita pemerintahan Jokowi sehingga menimbulkan protes. Jikalau ditinjau dari teori Pateda, ketidaksantunan itu terjadi dikarena unsur waktu dan tempat. Karena penutur lebih leluasa mengeluarkan pendapatnya tanpa berhadapan langsung dengan mitra tutur.

(2) Sa ae pak jokowi.. orang belakangnya hebat ya bikin video ini. Seakan terbalik dan semua terkagum. Tapi gw gak.. fak \#gantipencitraan.

Pada data (2) di atas menunjukkan perilaku ketidaksantunan berbahasa termotivasi yang dilakukan oleh warganet. Dikatakan sebagai perilaku ketidaksantunan termotivasi karena penutur mempunyai niatan langsung mengarahkan komentarnya pada Presiden Joko Widodo yang ditandai kalimat "Sa ae pak jokowi.. orang belakangnya hebat ya bikin video ini. Seakan terbalik dan semua terkagum. Tapi gw gak.. fakk \#gantipencitraan". Walaupun terdapat kalimat memuji yang ditandai dalam kalimat "Sa ae pak jokowi.. orang belakangnya hebat ya bikin video ini ... semua terkagum". Akan tetapi, jika melihat konteksnya, kalimat tersebut tetap mengandung unsur ketidaksantunan berbahasa yang termotivasi berupa sindirian. Terlebih pada kalimat lanjutannya yaitu "Tapi gw gak.. fakk \#gantipencitraan" yang mengandung bahasa makian dan perintah kepada seorang presiden untuk menghentikan tindakan pencitraan. Jika ditinjau dari akronim SPEAKING Hymes dalam huruf A (bentuk ujaran), K (sarkasme) serta N (norma interaksi) tentu perilaku demikian melanggar kesantunan dalam berbahasa. 
Terlebih penutur menggunakan kata makian dan sindiran yang ditunjukkan langsung ke kepala negara. Jika tinjau dengan teori Criper dan Widdowson maupun Pateda, kesantunan dilanggar karena didukung dengan tempat dan pesan yang disampaikan oleh iklan.

\section{Ketidaksantunan Tidak Termotivasi}

Ketidaksantunan tidak termotivasi adalah tindak ketidaksantunan yang tidak bertujuan tidak santun. Tidak diniatkan artinya tidak memahami bahwa hal yang dilakukan penutur tidak santun. Ketidak-pahaman tersebut dapat disebabkan berbagai faktor budaya yang berbeda, pemahaman konteks yang berbeda atau faktor kedekatan. Ketidaksantunan tidak termotivasi yang dilakukan oleh warganet dalam kolom komentar iklan kinerja pemerintah Presiden Joko Widodo bertajuk "2 Musim, 65 Bendungan" dapat dilihat dalam data berikut ini. (3) Pak Diklaten Jalannya Dibenarin Yang Bolong-Bolong, Udah Nyawa Teman Saya Meninggal Kemarin Berangkat Sekolah Karna Ngehindar Jalan Berlobang Terus Jatuh Karna Di Tempat Saya Banyak Truk Nambang Pasir Merapi, Mohon DiTanggapi Pak!

Pada data (3) di atas menunjukkan perilaku ketidaksantunan berbahasa tidak termotivasi yang dilakukan oleh warganet dalam iklan kinerja pemerintah residen Joko Widodo bertajuk "2 Musim, 65 Bendungan". Komentar tersebut dianggap sebagai perilaku ketidaksantunan tidak termotivasi karena tidak terdapat unsur ketidaksantunan berbahasa yang ditunjukkan secara langsung untuk Presiden Joko Widodo. Hal itu dapat dilihat dari kata 'Pak' dan 'mohon'. Walaupun secara konteknya penutur sedang memerintah kepala negara. Jika dilihat dari akronim SPEAKING yang dikemukakan Hymes dalam huruf A (bentuk ujaran) serta N (norma interaksi). Ketidaksantunan dalam huruf $\mathrm{A}$ dikarenakan penutur mengemukakan pendapatnya dalam penulisan huruf kapital yang menegaskan amarah dan ketidaksukaan. Sementara ketidaksantunan dalam huruf $N$ dikarenakan penutur melanggar norma interaksi dengan memerintah kepala negara. Ditinjau dari teori Criper dan Widdowson dan Pateda, ketidaksantunan itu terjadi didorong tempat dan pesan yang dari iklan.
(4) Maaf Bapak Jokowi untuk pilpres 2019 yg tadinya sy bulat utk paslon Jkw Maaruf, kok akhir2 ini spt roda berputar agak berpikir ukt melirik kubu sebelah ya, apalagi bbrapa pekan kemarin opini Ma'aruf Amin ttng titel ulama maaf menurut sy agak arogan ya, justru kebalikan dg Prabowo yg akhir2 ini sopan dan santun, hati2 dalam bertindak. Justru dr Pak Jokowi sndiri hemat sy akhir2 ini maaf agak lebay dan membanggakan diri sendiri. Hati2 pak dlm bertindak, dan Pak Ma'aruf juga hati2 jangan terlalu tersulut emosi. Menempatkan emosi yang pas spt pak JK, kl tdk byk simpatisan bs berpaling, itu hemat saya. Seandainya sj dg pak Mahfud MD dan berani dri ronrongan orang2 sekitar. Semoga ini bkn pilihan blunder.

Pada data (4) di atas menunjukkan ketidaksantunan berbahasa tidak termotivasi yang dilakukan oleh warganet. Dikatakan sebagai ketidaksantunan tidak termotivasi dikarenakan penutur dalam konteks komentarnya tidak bertujuan tidak santun. Hal itu terlihat dari penyampaian pen-dapatnya, penutur beberapa kali menuliskan kata 'maaf' dan kata 'bapak dan pak' yang ditunjukkan pada Presiden Joko Widodo. Walaupun demikian, komentar tersebut dianggap sebagai bahasa yang tidak santun jika ditinjau dari akronim SPEAKING yang dikemukakan Hymes dalam huruf A (bentuk ujaran), $\mathrm{K}$ (sarkasme) serta $\mathrm{N}$ (norma interaksi). Ketidaksantunan dalam huruf A dikarenakan penutur seakan meremehkan titel mitrapolitik Presiden Joko Widodo, memerintah Presiden Joko Widodo dan membandingkannya dengan Prabowo. Ketidaksantunan dalam huruf K karena penutur menggunakan kata sarkasme dalam komentarnya yang ditandai kata 'lebay' yang ditunjukkan pada Presiden Joko Widodo. Sementara ketidaksantunan dalam huruf $\mathrm{N}$ dikarenakan penutur melanggar norma interaksi dengan memerintah kepala negara.

\section{Ketidaksantunan Berbahasa Warganet Menurut Pandangan Brown dan Levinson}

Brown dan Levinson mengemukakan bahwa ketidaksantunan didasari oleh tindakan face threatning act (mengancam muka). Tindakan itu dibagi menjadi dua kategori yaitu tindakan yang mengancam muka negatif mitra tutur dan 
tindakan yang mengancam muka positif. Dua tindakan mengancam muka tersebut terlihat dilakukan oleh warganet dalam kolom komentar iklan kinerja pemerintah Presiden Joko Widodo bertajuk "2 Musim, 65 Bendungan". Adapun data yang menunjukkan ketidaksantunan berbahasa tersebut diuraikan berikut ini.

\section{Tindakan yang Mengancam Muka Negatif Lawan Tutur}

Tindakan mengancam muka negatif lawan tutur meliputi a) tindakan yang mengakibatkan mitra tutur menyetujui atau menolak melakukan, seperti ungkapan: orders and requests, suggestions, advice, reminding threats, warnings, dears (memerintah, cemoohan, memberi saran, memberi nasihat, mengingatkan, mengancam, memperingatkan maupun menentang); (b) tindakan yang mengungkapkan upaya penutur melakukan sesuatu dan memaksa mitra tutur untuk menerima dan menolak tindak, seperti ungkapan offers, promises (menawarkan dan berjanji); maupun (c) tindakan yang mengungkapkan keinginan penutur untuk melakukan sesuatu terhadap mitra tutur atau yang dimiliki oleh lawan tutur, seperti ungkapan: compliments, expressions of strong emotions towerd, hatred, anger (memberi ucapan selamat, mengagumi, membenci, dan marah). Tindakan mengancam muka negatif itu dapat dilihat pada data berikut ini.

(5) Ini iklan yg katanya nongol di bioskop?? busett muke gile dikata nonton di bioskop gratis kek nonton tipe di rumah?.. udah bayar mahal disuruh nonton iklan kek bgini, kalo iklan nya bisa di skip kek di youtobe sih gak masalah dah...

Pada data (5) di atas menunjukkan ketidaksantunan berbahasa mengancam muka negatif lawan tutur. Ketidaksantunan tersebut terjadi dikarenakan penutur tidak menyetujui atau menolak adanya penayangan iklan di bioskop. Ketidaksetujuan itu disertai dengan kalimat cemoohan, menentang dan memberi saran. Cemoohan dan pertentangan tersebut dapat dilihat dari frasa "busett muke gile" dan "dikata nonton di bioskop gratis". Frasa tersebut juga menandai adanya kemarahan di dalam diri penutur. Frasa pemberian saran dapat dilihat dari kalimat "kalo iklan nya bisa di skip kek di youtobe sih gak masalah dah...”. Jika ditinjau dari akronim SPEAKING yang dikemukakan Hymes melanggar peristiwa komunikasi dalam huruf $\mathrm{K}$ karena menggunakan bahasa sarkasme dan huruf $\mathrm{N}$ karena melanggar norma dalam berinteraksi. Menurut Criper dan Widdowson dan Pateda ketidaksantunan itu terjadi karena pesan dari iklan dan waktu.

(6) Harusnya setelah iklan ini disambung pernyataan dirut bulog mengenai import beras yg sampai membuat bulog ga punya gudang buat nyimpan wkwkwk.

Pada data (6) di atas menunjukkan ketidaksantunan berbahasa mengancam muka negatif lawan tutur. Ketidaksantunan tersebut terjadi dikarenakan penutur tidak menyetujui isi dari iklan yang ditayangkan. Ketidaksetujuan itu dikarenakan pemerintah Joko Widodo mengiklankan keberhasilkan pembangunan infrastruktur bendungan dan waduk untuk meningkat hasil pangan masyarakat Indonesia namun melakukan impor beras dengan skala besar. Komentar tersebut dianggap tidak santun dikarenakan saran yang dianjurkan disertai dengan sindiran dan ketawa. Ketidaksantunan mengancam muka negatif lawan tutur tersebut dilakukan dengan cara memerintah, mencemooh, memberi saran dan menetang. Jika ditinjau dari akronim SPEAKING yang dikemukakan Hymes peristiwa bahasa tersebut melanggar komunikasi dari huruf $\mathrm{N}$ mengenai norma interaksi karena melakukan penyindiran yang disertai tertawa. Terlebih ditunjukkan kepada kepala negara. Ditinjau dari teori Criper dan Widdowson dan Pateda bahwa sikap demikian dilatarbelakangi oleh pesan iklan dan tempat.

\section{Tindakan yang Mengancam Muka Positif Lawan Tutur}

Tindakan mengancam muka positif lawan tutur meliputi a) tindakan yang memperlihatkan bahwa penutur memberi penilaian negatif terhadap mitra tutur, seperti ungkapan mengenai disapproval, criticism, contempt or ridicule, complaints and reprimands, accusations, insults (meng-ungkapkan sikap tidak setuju, mengkritik, tindakan merendahkan, keluhan, kemarahan, dakwaan maupun penghinaan); b) tindakan yang memperlihatkan sikap tidak peduli penutur terhadap muka positif lawan tutur, seperti ungkapan contradictions or disagree-ments, challenges, emitions, irreverence, mention of 
taboo topiks, including those that are inappropriate in the context (perten-tangan, ketidaksetujuan, emosi, ungkapan yang tidak sopan, membicarakan hal yang dianggap tabu dan tidak selayaknya dalam situasi, yaitu penutur menunjukkan sikap tidak menghargai nilai-nilai mitra tutur dan tidak ingin meninggalkan hal yang ditakuti mitra tutur; c) ungkapan mengenai bad news about $H$, or good news (boasting) abaout $S$ ( $S$ indicates that he willing to cause distress to $H$, and/or doesn't care about H's feeling) (ungkapan kabar buruk mengenai lawan tutur atau menyombongkan berita baik, yaitu menunjukkan bahwa penutur tidak segan-segan menunjukkan hal-hal yang kurang menyenangkan pada mitra tutur dan tidak mempedulikan perasaan lawan tutur); d) ungkapan hal-hal yang membahayakan serta topik yang bersifat memecah belah pendapat, seperti masalah topik, ras, agama dan pembebasan wanita. Dalam hal itu penutur menciptakan suasana yang berpotensi untuk mengancam muka mitra tutur dan penutur membuat atmosfir yang berbahaya terhadap mitra tutur; e) ungkapan yang tidak koopratif dari penutur terhadap mitra tutur yaitu penutur menyela pembicaraan mitra tutur, menyatakan hal-hal yang menunjukkan tidak kepedulian. Penutur menunjukkan bahwa dia tidak mempedulikan keinginan muka negatif maupun muka positif mitra tuturnya; f) unkapanungkapan mengenai sebutan atau hal-hal yang menunjukkan status mitra tutur pada perjumpaan pertama. Situasi itu mungkin penutur membuat identifikasi yang keliru mengenaimitra tutur yang melukai perasaan atau mempermalukannya baik secara sengaja ataupun tidak. Tindakan mengancam muka positif itu dapat dilihat pada data berikut ini.

(7) Pak jokowi yang terhormat anda tahu? Bapak hanya melanjutkan program pembangunan di era SBY sebagian ada yang cuma finishing. Tak lupa berapa fasilitas negara anda klaim sana sini. Prestasi itu diakui tak butuh pengakuan.

Pada data (7) di atas menunjukkan adanya ketidaksaksantunan berbahasa mengancam muka positif yang dilakukan warganet. Ketidaksantunan tersebut karena adanya indikasi tindakan yang mem-perlihatkan penutur memberi penilaian negatif pada mitra tutur dan tindakan yang memperlihatkan sikap tidak peduli penutur terhadap muka positif mitra tutur. Penilaian negatif yang dilakukan penutur terhadap mitra tutur berupa ungkapan tidak setuju, mengkritik, tindakan merendahkan, keluhan, kemarahan, dakwaan, penghinaan. Tindakan yang memperlihatkan sikap tidak peduli penutur terhadap muka positif lawan tutur berkaitan dengan pertentangan, ketidak-setujuan penutur dengan iklan yang ditayangkan yang kemudian melahirkan emosi. Tindakan yang memperlihatkan penutur memberi penilaian negatif pada lawan tutur dan tindakan yang memperlihatkan sikap tidak peduli penutur terhadap muka positif lawan tutur timbul dalam diri penutur akibat tidak adanya penjelasan pembangunan di dalam iklan yang mengatakan bahwa pembangunan bendungan dan waduk itu merupakan program lanjutan dan program baru. Ditinjau dari teori Hymes mengenai peristiwa bahasa dalam akronim SPEAKING, warganet sebagai penutur melanggar norma interkasi. Ditinjau Criper dan Widdowson dan Peteda bahwa pelanggaran kesantunan itu terjadi kerena pesan iklan dan tempat kejadian.

(8) Utang kita sudah brpa bro? Dana haji udh kpakai brpa bro? Persekusi di negeri demokrasi gmna bro? Import garam besar"an ya bro? Rupiah makin ngga berhrga ya bro? Salah satu aja beritanya bro,,, pemerintah GAGAL.

Pada data (8) di atas menunjukkan ketidaksantunan berbahasa mengancam muka positif lawan tutur. Adapun ketidaksantunan yang dilakukan warganet pada lawan tutur yaitu mengenai tindakan yang memperlihatkan penutur yang memberikan penilaian negatif terhadap lawan tutur dalam ungkapan sikap tidak setuju, mengkritik, tindakan merendahkan, keluhan, kemarahan, dakwaan, penghinaan. Tindakan yang memperlihatkan sikap tidak peduli penutur terhadap muka positif lawan tutur yang berkaitan dengan ungkapan pertentangan, ketidaksetujuan atau tantangan, emosi, ungkapan yang tidak sopan, membicarakan hal yang dianggap tabu ataupun yang tidak selayaknya dalam situasi. Maupun ketidaksantunan yang dilakukan karena menyuarakan ungkapanungkapan mengenai sebutan. Ketidaksantunan 
dalam pemberian penilaian negatif berupa ungkapan tidak setuju, mengkritik, tindakan merendahkan, keluhan, kemarahan, dakwaan, penghinaan. Hal itu didasari oleh tindakan pemerintah Presiden Joko Widodo yang menggunakan dana haji, adanya persekusi, pengimporan garam dengan skala besar dan merosotnya nilai rupiah yang kemudian memunculkan spekulasi pemerintah yang gagal. Berbanding terbalik yang dikemuka-kan oleh Presiden Joko Widodo dalam iklannya bahwa pembangunan yang dilakukan untuk meningkatkan kesejahteraan rakyat. Tindakan penilaian itu memunculkan sikap ketidakpedulian, pertentangan, ketidak-setujuan atau tantangan, emosi dan ungkapan yang tidak sopan. Ketidaksantunan men-gancam muka positif lawan tutur yang dilakukan penutur karena menyuarakan ungkapan sebutan 'Bro' yang ditunjukkan pada Presiden Joko Widodo. Jika ditinjau dari akronim Speaking yang dikemukakan Hymes dalam peristiwa bahasa, ketiga ketidaksantunan berbahasa mengancam muka positif lawan tutur tersebut melanggar komunikasi dari huruf $\mathrm{N}$ mengenai norma interaksi karena melakukan penilaian negatif, ketidakpedulian dan penggunaan sebutan yang tidak tepat. Dilihat dari teori Criper dan Widdowson dan Pateda ketidaksantunan terjadi karena didukung oleh pesan iklan dan tempat peristiwa bahasa.

\section{Ketidaksantunan Berbahasa Warganet Menurut Pandangan Culpeper}

Culpeper mengemukakan terdapat lima kategori dalam ketidaksantunan berbahasa, meliputi ketidaksantunan secara langsung, ketidaksantunan positif, ketidaksantunan negatif, sarkasme atau kesantunan semu maupun menahan kesantunan. Kelima teori yang dikemukakan Culpeper dalam penelitian ini hanya tiga kategori yang ditemukan dalam tuturan warganet. Ketiga kategori itu meliputi ketidaksantunan secara langsung, sarkasme atau kesantunan semu dan menahan kesantunan.. Ketiga kategori ketidaksantunan berbahasa tersebut dapat dilihat pada data berikut ini.

\section{Ketidaksantunan Secara Langsung}

Bald on record impoliteness (ketidaksantunan secara langsung) merupakan tinakdan mengancam muka secara langsung, jelas, tidak ambigu, dan ringkas dalam keadaan wajah tidak relevan atau diminimalkan tidak perlu dihubungkan dengan muka. Ketidaksantunan berbahasa secara langsung dapat dilihat pada data berikut.

(9) Sa ae pak jokowi.. orang belakangnya hebat ya bikin video ini. Seakan terbalik dan semua terkagum. Tapi gw gak.. fakk \#gantipencitraan.

Pada data (9) di atas menunjukkan ketidaksantunan berbahasa secara langsung. Ketidaksantunan bahasa yang dilakukan warganet dalam kolom komentar iklan tersebut secara langsung ditunjukkan pada Presiden Joko Widodo. Dikatakan ketidaksantunan berbahasa secara langsung karena penutur menulisnya secara jelas, ringkas dan tidak ambigu. Hal itu ditandai dengan sebutan nama 'Jokowi' karena sebutan itu dilekatkan pada Presiden Joko Widodo. Ketidaksantunan bahasa itu muncul diakibatkan penutur tidak terima dengan iklan yang ditayangkan oleh pemerintahan Presiden Joko Widodo. Warganet beranggapan bahwa iklan yang ditayangkan itu merupakan bentuk pencitraan dari Presiden Joko Widodo. Penutur pula menegaskan bahwa dirinya tidak akan terkagum. Ketidaksantunan semakin dirasakan dalam tuturan itu ditegaskan pada kata 'fak' yang mengadung unsur cemoohan dari penutur secara langsung pada Presiden Joko Widodo. Jika tinjau dari teori peristiwa bahasa Hymes dalam akronim SPEAKING tuturan yang dilakukan oleh warganet itu melanggar norma interaksi dan meng-gunakan bahasa sarkasme. Ditinjau dari teori Criper dan Widdowson maupun Pateda, ketidaksantun timbul karena dukung oleh peristiwa bahasa yang berkaitan dengan pesan dari iklan dan tempat tuturan.

\section{Sarkasme atau Kesantunan Semu}

Sarcasm or mock politeness (sarkasme atau kesantunan semu) merupakan ke-santunan yang tidak tulus, berpura-pura atau tampak santun dipermukaan. Kesantunan semu yang dilakukan warganet dapat dilihat pada data berikut.

(10)udah nggak usah pada berdebat ni bendungan juga presiden yang sebelumnya juga ada jasanya juga. Mang bangun nggk perlu survey, buka lahan, DED sam perencanaan. Kalau tinggal bangun atau 
nerusin aj sih gampang. Intinya Jangan

Lupakan Jasa Presiden Sebelumnya.

Pada data (10) di atas menunjukkan adanya ketidaksantunan berbahasa sarkasme atau ketidaksnatunan semu yang dilakukan oleh warganet. Aktivitas bahasa yang dilakukan penutur di dalam kolom komentar iklan kinerja pemerintah Presiden Joko Widodo dinilai sarkasme. Penutur pada awal komentarnya sebagai penengah, namun di tengah-tengah komentarnya penutur memihak pihak lain dengan mengatakan bahwa iklan bendungan yang dinyatakan hasil kerja pemerintahan Presiden Joko Widodo selama dua periode itu tidak semuanya benar. Menurut penutur dalam pembangunan infrastruktur harus ada survei, buka lahan, DED dan perencanaan yang matang. Penutur menegaskan jikalau pembangun infrastruktur program lanjutan merupakan persoalan mudah dalam mengerjakannya. Aktivitas berbahasa yang demikian tentu melanggar kesantunan berbahasa karena penutur menggunakan strategi kesantunan yang jelas tidak tulus, berpura-pura atau tampak santun di dalam permukaan saja. Aktivitas bahasa yang dilakukan warganet tersebut jika ditinjau dari teori peristiwa bahasa Hymes dalam akronim SPEAKING melanggar $\mathrm{K}$ berisi sarkasme dan unsur $\mathrm{N}$ berkaitan dengan norma interaksi. Ditinjau dari pendapat Criper dan Widdowson maupun Pateda, ketidak-santunan terjadi karena didukung pesan iklan dan waktu.

\section{Menahan Kesantunan}

Withhold politeness (menahan ke-santunan) ialah perilaku yang memper-lihatkan sikap penutur yang tidak melakukan kesantunan seperti yang diharapkan, misal-nya tidak mengucapkan terima kasih kepada mitra tutur yang memberikan hadiah, ucapan selamat maupun bantuan. Menahan ke-santunan yang dilakukan warganet dapat dilihat pada data berikut.

(11)Pak jokowi yang terhormat anda tahu?

Bapak hanya melanjutkan program pembangunan di era SBY sebagian ada yang cuma finishing. Tak lupa berapa fasilitas negara anda klaim sana sini. Prestasi itu diakui tak butuh pengakuan.

Pada data (11) di atas menunjukkan ketidaksantunan berbahasa menahan kesantunan. Kalimat yang tulis warganet tersebut dianggap sebagai perilaku ketidaksantunan berbahasa dalam menahan kesantunan dikarenakan tidak adanya ucapan rasa terima kasih kepada pemerintahan Presiden Joko Widodo dalam melakukan pembangunan bendungan. Upaya menahan kesantunan berbahasa tersebut dikarenakan penutur meyakini bahwa bendungan yang dibangun tidak sepenuhnya merupakan hasil kerja dari program pemerintahan Presiden Joko Widodo karena itu merupakan program kerja presiden sebelumnya dan pemerintah Presiden Joko Widodo yang hanya meneruskannya. Penahanan kesantunan pula dilakukan oleh penutur karena tidak adanya pernyataan resmi dari Presiden Joko Widodo bahwa pembangunan bendungan tersebut merupakan program lanjutan dari presiden sebelumnya. Penutur menganggap bahwa itu merupakan bentuk pengklaiman dari program kinerja orang lain. Namun demikian, jika seseorang memiliki perilaku yang santun tentu akan menghindari aktivitas menahan kesantunan dan menyampaikan rasa terima kasihnya pada pemerintahan Joko Widodo walaupun bendungan yang dikerjakan merupakan program lanjutan dari presiden sebelumnya. Jika dilihat dari teori Hymes mengenai peristiwa bahasa dalam akronim SPEAKING, warganet tersebut melanggar unsur K karena berhubungan dengan kata sarkasme dan unsur $\mathrm{N}$ berhubungan dengan norma interaksi. Jika ditinjau dengan teori Criper dan Widdowson, ketidaksantunan itu terjadi karena adanya pesan iklan. Menurut Pateda, penutur berprilaku tidak santun dikarenakan tidak bertemu langsung dengan mitra tutur.

\section{KESIMPULAN}

Berdasarkan pembahasan yang telah diuraikan di atas dapat disimpulkan bahwa ketidaksantunan berbahasa yang dilakukan warganet dalam kolom komentar iklan kinerja pemerintahan Presiden Joko Widodo yang bertajuk "2 Musim, 65 Bendungan" yang dikaji dengan teori ketidaksantunan berbahasa Mils, ditemukan perilaku ketidaksantunan berbahasa termotivasi dan ketidaksantunan berbahasa tidak termotivasi. Pengkajian dengan teori Brown dan Levinson ditemukan perilaku ketidak-santunan berbahasa berupa tindakan yang mengancam muka negatif dan positif lawan tutur. 
Ketidaksantunan berbahasa meng-ancam muka negatif berupa tindakan yang mengakibatkan lawan tutur tidak menyetujui melakukan sesuatu sehingga menimbulkan sikap memerintah, cemoohan, memberi saran, memberi nasihat, mengingatkan, mengancam, memperingatkan dan menentang. Tindakan yang mengancam muka positif lawan tutur meliputi tindakan yang memperlihatkan memberi penilaian negatif terhadap lawan tutur sehingga timbul ungkapkan tidak setuju, mengkritik, tindakan merendahkan, keluhan, kemarahan, dakwaan, penghinaan, tindakan yang memperlihatkan sikap tidak peduli penutur terhadap lawan tutur berupa sikap pertentangan, ketidaksetujuan atau tantangan, emosi dan ungkapan yang tidak sopan, maupun tindakan yang menggunakan ungkapanungkapan mengenai sebutan. Pengkajian dengan teori Culpeper ditemukan perilaku ketidaksantunan berbahasa ber-kaitan dengan ketidaksantunan berbahasa secara langsung, sarkasme atau kesantunan semu dan menahan kesantunan. Melalui peristiwa bahasa dalam akronim SPEAKING yang dikemukakan Hymes, unsur yang dilanggar warganet dalam kolom komenter tersebut yaitu A mengenai bentuk ujaran yang digunakan, $\mathrm{K}$ berkaitan dengan bahasa sarkasme dan unsur $\mathrm{N}$ mengenai norma interaksi. Teori Criper dan Widdowson maupun Pateda ketidaksantunan dilatar-belakangin oleh pesan iklan dan waktu maupun tempat tuturan.

\section{SARAN}

Analisis dan interpretasi data yang dilakukan dalam penelitian ini diduga masih belum dikupas terlalu dalam menggunakan aspek peristiwa bahasa. Sehingga ketidaksantunan berbahasa yang dilakukan warganet dalam kolom komentar iklan "2 Musim, 65 Bendungan" belum ditinjau secara menyeluruh. Implikasi teori yang dipaparkan dalam penelitian ini dapat memberikan gambaran kepada penelitian selanjutnya dalam menelaah ketidaksantunan berbahasa dalam pelbagai objek penelitian. Peneliti selanjutnya pula dapat menemukan gambaran bahwa dalam menelaah ketidaksantunan berbahasa tidak hanya memfokuskan pada teori ketidaksantunan namun dapat dikorelasikan dengan teori peristiwa bahasa agar permasalahan penelitian dapat dikaji lebih menyeluruh dalam pelbagai aspek.

\section{UCAPAN TERIMA KASIH}

Segala bentuk aktivitas tentu tidak akan berjalan dengan baik tanpa ada bantuan dari pelbagai pihak. Puji syukur diucapkan kehadirat Allah SWT, yang telah memberikan ilmu dan nikmat sehat, dalam proses penyelesaian penelitian ini. Terima kasih kepada ketua STKIP Harapan Bima telah memberikan fasilitas dalam menunjang penelitian. Terima kasih pula disampaikan pada rekan-rekan penelitian yang membantu proses penyelesaian penelitian ini.

\section{DAFTAR PUSTAKA}

Allen, J.P.B dan S. Pit Corder. (1975). Papers in Applied Linguistics (hlm.185). London Oxford University Press.

Brown dan Levinson. (1987). Politeness: Some Universals In Language Use (hlm.34-45). New York: Cambridge University Press.

Culpeper, Jonathan. (1996). "Towards an Anatomy of Impoliteness". Journal of Pragmatic, 349-367.

Detiknews. 20 September, 2018. Kominfo: Iklan 'Bendungan Jokowi' di Bioskop Bukan Kampanye, hlm. 1.

Ekawati, Mursia. (2017). Kesantunan Semu pada Tindak Tutur Ekspresif Marah dalam Bahasa Indonesia, Jurnal Adabiyyāt, 1 (1), 2.

Fatimah, Nuraini dan Zainal Arifin. (2014). Strategi Ketidaksantunan Culpeper dalam Berbahasa Lisan di Sekolah, Prosiding Seminar Nasional (Hlm.89). Surakarta, Indonesia: Fakultas Keguruan dan Ilmu Pendidikan, Universitas Muhammadiyah Surakar-ta.

Gunawan, Fahmi. (2013). Wujud Kesantun-an Berbahasa Mahasiswa terhadap dosen di STAIN Kendari: Kajian Sosiopragmatik, Jurnal Arbitrer, 1 (1), 8.

Kominfo: Pengguna Internet di Indonesia 63 Juta Orang. Diakses 13 September 2020, dari website Kemenkominfo: https://kominfo.go.id/index.php/content/ detail. 
Mills, Sara. (2003). Gender and Politeness (Hlm.122-139). Cambridge: Cambrid-ge University Press.

Muslim, Bukhori. (2017). Penyimpangan Teori Brown dan Levinson dalam Tindak Tutur Peserta Talk Show Indonesia Lawyers Club (ILC) di TV One dan Relevansinya terhadap Pembelajaran Bahasa Indonesia di SMA, Jurnal Retorika, 3 (1), 104.

Pateda, Mansoer. (1987). Sosiolinguistik (hlm.22-23). Bandung: Angkasa.

Rahardi, Kunjana, dkk. (2016). Pragmatik: Fenomena Ketidaksantunan Berba-hasa (hlm.59-67). Jakarta: Erlanggga.

Tribunnews. 12 September, 2018. Soal 'Iklan Jokowi' di Bioskop, Fadli Zon: Jelas Mubazir, hlm. 1.

Wahyudin, Ahmad. (2013). Menyikapi Ketidaksantunan Bahasa di Media Massa Cetak, Prosiding Seminar Nasional (Hlm.310). Surakarta, Indonesia: Fakultas Keguruan dan Ilmu Pendidikan, Universitas Muhammadiyah Surakarta.

Widodo, Joko. (2018). 2 Musim, 65 Bendungan, https//www.youtobe.co-m/wacth?v=4e.

Wijayanto, Agus. (2014). Ketidaksantunan Berbahasa: Penggunaan Bahasa Kekerasan di Sinetron Bertema Kehidupan Remaja, Prosiding Seminar Nasional (Hlm.116). Su-rakarta, Indonesia: Fakultas Keguruan dan Ilmu Pendidikan, Universitas Muhammadiyah Surakarta. 